\title{
EFFECT OF A NEW ANGIOTENSIN CONVERTING ENZYME INHIBITOR MK 421 AND ITS LYSINE ANALOGUE ON THE COMPONENTS OF THE RENIN SYSTEM IN HEALTHY SUBJECTS
}

\author{
D.B. BRUNNER, G. DESPONDS, J. BIOLLAZ, I. KELLER, F. FERBER, \\ H. GAVRAS, H.R. BRUNNER \& J.L. SCHELLING \\ Department of Medicine, Centre Hospitalier Universitaire, \\ Lausanne, Switzerland
}

1 MK 421 and its lysine analogue are two new inhibitors of angiotensin converting enzyme. Ten $\mathrm{mg}$ of both compounds were each given p.o. to 12 normotensive volunteers to determine their effect on the various components of the renin angiotensin aldosterone system.

2 Plasma converting enzyme activity decreased to very low levels within 3 to $4 \mathrm{~h}$ to recover only slowly over the next $72 \mathrm{~h}$. Plasma angiotensin II and aldosterone also fell but returned to baseline within $24 \mathrm{~h}$, whereas plasma renin activity rose reflecting the low angiotensin II levels.

3 There was a close correlation between both angiotensin II and aldosterone levels and the logarithm of plasma converting enzyme activity demonstrating that angiotensin II and aldosterone fell only when converting enzyme activity was reduced to very low levels.

4 Mean hourly urinary sodium excretion increased markedly 6 to $10 \mathrm{~h}$ post-drug, while blood pressure decreased slightly. Both drugs were well tolerated.

5 Thus $10 \mathrm{mg}$ of MK 421 or its lysine analogue given orally are effective and long acting angiotensin converting enzyme inhibitors.

\section{Introduction}

In 1976 the first orally active compound that inhibits angiotensin converting enzyme, i.e. captopril or SQ 14,225 , became available for clinical investigation (Ferguson, Turini, Brunner, Gavras \& McKinstry, 1977). During the last few years it has become evident that blockade of the renin angiotensin system by this compound provides a very effective approach to control clinical and experimental hypertension (Gavras, Brunner, Turini, Kershaw, Tifft, Cuttelod, Gavras, Vukovich \& McKinstry, 1978; Brunner, Gavras, Waeber, Kershaw, Turini, Vukovich, McKinstry \& Gavras, 1979; Case, Atlas, Laragh, Sealey, Sullivan \& McKinstry, 1978) and to treat congestive heart failure (Davis, Ribner, Keung, Sonnenblick \& LeJemtel, 1979; Turini, Brunner, Gribic, Waeber \& Gavras, 1979). Unfortunately, while there exists no doubt that captopril is a very effective drug, its introduction to general clinical use is hampered by some potentially hazardous side-effects (British Medical Journal, 1980). Recently, a new group of compounds which also inhibit angiotensin converting enzyme have been synthetized. They have been tested in normal volunteers and found to markedly inhibit the pressor response to exogenous angiotensin I (Biollaz, Burnier, Turini, Brunner, Porchet, Gomez, Jones, Ferber, Abrams Gavras \& Brunner, 1981). The present study was designed to evaluate the effect of a single dose of these new inhibitors. MK 421 and a lysine analogue (LA), in normal volunteers on the various components of the renin angiotensin aldosterone pressor system. The results obtained suggest that both drugs have a prolonged duration of action and that they very effectively reduce plasma converting enzyme activity, angiotensin II and aldosterone levels and thereby increase sodium diuresis.

\section{Methods}

\section{Subjects}

Twelve normotensive male volunteers aged 22 to 33 years, weighing between 59 and 82 (mean $69.4 \pm 2.2$ ) $\mathrm{kg}$ were included in the study. The protocol was approved by the Hospital Ethics Committee. The nature and the purpose of the study were explained to each volunteer and written informed consent was obtained. Each had a medical history taken and underwent a complete physical examination. For safety evaluation, routine laboratory tests were done before and after the administration of the experimental drugs.

C) Macmillan Publishers Ltd 1981 


\section{Design of the study}

Throughout the investigation, the subjects were maintained on a free regular salt intake. On the morning of day 1 , the volunteers came to the hospital out-patient department at $07.00 \mathrm{~h}$ after an overnight fast. They had been instructed to drink $150 \mathrm{ml}$ of tap water after rising. Upon arrival, they were installed in a comfortable armchair and an intravenous catheter was inserted into an antecubital vein. Blood samples for the measurement of plasma converting enzyme activity were drawn immediately prior to drug administration at $08.00 \mathrm{~h}$ and $15,30,60$ and $90 \mathrm{~min}, 2$, $3,4,6,8,10,24,48$ and $72 \mathrm{~h}$ later. In addition, blood samples for the measurement of plasma renin activity, plasma angiotensin II and aldosterone levels were drawn at times $0,1,4,10$ and $24 \mathrm{~h}$ in 6 of the 12 subjects after MK 421 and in the remaining 6 after the lysine analogue. Starting on the day before the administration of the experimental drug (day -1), 24 h urines were collected for four consecutive days. On day 1 , following the administration of the drug, urines were collected at 2 hourly intervals for $10 \mathrm{~h}$. Blood pressure and heart rate were monitored at half hourly intervals during the first $4 \mathrm{~h}$ and then hourly up to the tenth hour. For the same period of time the subjects remained seated in the armchair and were only allowed to rise for voiding and to eat lunch between hours 4 and 5 . Ten hours following the drug administration, the subjects left the hospital to return on the following mornings up to the fourth day post-drug.

\section{Drugs}

Two different compounds, MK 421 ( $N$-[(S)1-(ethoxycarbonyl)-3-phenylpropy1]-L-alanyl-Lproline) and its lysine analogue $\left(N^{2}-[(\mathrm{S})-1\right.$-carboxy-3phenylpropyl]-L-lysyl-L-proline) were investigated. Capsules containing $10 \mathrm{mg}$ of each of the compounds were supplied by Merck Sharp and Dohme, Rahway, New Jersey. A single dose of $10 \mathrm{mg}$ was administered orally with $150 \mathrm{ml}$ of tap water at $08.00 \mathrm{~h}$. Each subject received both compounds at an interval of 1 week in a double-blind randomised cross over fashion.

\section{Analytical methods}

The methods used to determine plasma renin and converting enzyme activity and plasma aldosterone concentrations have been reported previously (Brunner et al., 1979). Plasma angiotensin II concentrations were measured using a modification of the method described by Dusterdieck \& McElvee (1971). The antibody was provided by Dr W. Vetter from Zurich. Cross reactivity of this antibody with angiotensin I is less than $0.1 \%$. In our laboratory, recovery of added unlabelled angiotensin II ( 5 to $300 \mathrm{pg}$ ) varied between 96 and $103 \%$ and the coefficient of variation of a pool plasma (mean $7.7 \mathrm{pg} / \mathrm{ml}$ ) in 24 consecutive assays has been found to be $5.6 \%$. In some subjects, angiotensin I levels have also been determined; the method used was a modification of that described by Waite (1973). Blood pressure was always measured with the subjects seated using a sphygmomanometer. Creatinine and electrolytes as well as the parameters included in the safety assessment were determined by the routine laboratory of the hospital.

The significance of differences between means was evaluated by the Student's $t$-test, on paired or unpaired samples as indicated in the text. In addition relationships between two parameters were analysed using the least squares method. Unless otherwise indicated all results are given as mean and s.e.mean.

\section{Results}

\section{Blood pressure and heart rate}

Both compounds were well tolerated by all subjects and no untoward effects were observed. The blood pressure measurements obtained with both inhibitors are summarized in Table 1. Diastolic as well as systolic blood pressure were slightly but significantly lower between 3 and $10 \mathrm{~h}$ following the two drugs, whereas heart rate tended to be higher at $6 \mathrm{~h}$.

\section{Plasma converting enzyme activity}

Figure 1a illustrates the time course of plasma converting enzyme activity following administration of the two compounds. Plasma angiotensin converting enzyme activity decreased markedly to reach levels well below $10 \mathrm{nmol} \mathrm{ml}^{-1} \min ^{-1}$ between 4 and $10 \mathrm{~h}$ following administration of both drugs. At $24 \mathrm{~h}$, slight recovery of plasma converting enzyme activity was apparent but it had still not returned to control levels at $72 \mathrm{~h}$. While the response patterns induced by the two compounds were very similar, onset of action of MK 421 seemed slightly more rapid than that of its lysine analogue the differences at $1.5,2$ and $3 \mathrm{~h}$ being significant $(P<0.005)$. Similarly, the recovery of angiotensin converting enzyme activity appeared slightly faster following MK 421, differences again being significant at the 0.001 level 48 and $72 \mathrm{~h}$ following administration of the drugs.

To insure that in vitro there is no dissociation of the complex plasma converting enzyme-enzyme inhibitors, some converting enzyme measurements were repeated after storage of the plasma at $-20^{\circ} \mathrm{C}$ for an average of 5 months. Figure lb illustrates that over the entire range of levels measured there was no change in enzyme activity which could be attributed to storage of the samples. 
Renin, angiotensin II and aldosterone

Figure 2 illustrates the time course of plasma renin activity, plasma angiotensin II and aldosterone following administration of the two compounds. As could be expected, plasma renin (Figure 2a) increased to reach the highest levels at $4 \mathrm{~h}$; it remained slightly enhanced up to $24 \mathrm{~h}$. Angiotensin II levels (Figure 2b) decreased from $12.0 \pm 1.4$ to $6.9 \pm 3.2 \mathrm{pg} / \mathrm{ml}(P<$ $0.025)$ at $4 \mathrm{~h}$ with MK 421 and from $10.8 \pm 2.7$ to 7.2 $\pm 1.9 \mathrm{pg} / \mathrm{ml}(P<0.01)$ with the lysine analogue. Plasma angiotensin II remained low at $10 \mathrm{~h}$ but returned to baseline levels at $24 \mathrm{~h}$. Plasma aldosterone (Figure 2c) paralleled plasma angiotensin II, the lowest values being measured at 4 and $10 \mathrm{~h}(P<$ 0.025).

Relationship between plasma renin activity and angiotensin II during converting enzyme blockade

A positive correlation was found between plasma renin activity and angiotensin II measured 4 and $10 \mathrm{~h}$ following administration of the two inhibiting compounds (Figure 3). Thus, the highest values of plasma renin activity were accompanied by somewhat higher plasma angiotensin II levels. This correlation observed when angiotensin II levels were markedly reduced from baseline as pointed out above, was
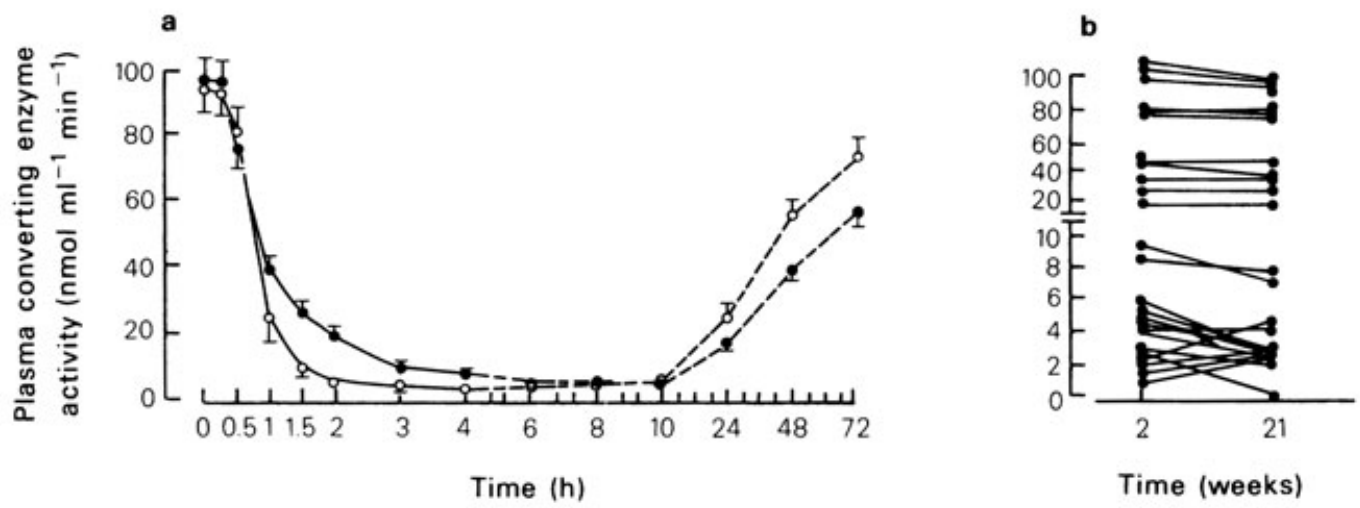

Figure 1 (a) Time course of plasma converting enzyme activity following oral administration of $10 \mathrm{mg}$ MK 421 (O) or its lysine analogue (LA, ) (mean \pm s.e.mean, $n=12$ ).

(b) With these compounds storage of plasma samples at $-20^{\circ} \mathrm{C}$ did not influence the determination of converting enzyme activity since repeat determinations several months later were unchanged.

Table 1 Blood pressure and heart rate following administration of $10 \mathrm{mg}$ p.o. of the parent compound MK 421 or its lysine analogue LA

\begin{tabular}{|c|c|c|c|c|}
\hline \multirow[b]{2}{*}{ Time (h) } & \multicolumn{2}{|c|}{$M K 421$} & \multicolumn{2}{|c|}{$L A$} \\
\hline & $\begin{array}{c}\text { Blood pressure } \\
(\mathrm{mmHg})\end{array}$ & $\begin{array}{l}\text { Heart rate } \\
\left(\min ^{-1}\right)\end{array}$ & $\begin{array}{l}\text { Blood pressure } \\
(\mathrm{mmHg})\end{array}$ & $\begin{array}{c}\text { Heart rate } \\
\left(\min ^{-1}\right)\end{array}$ \\
\hline 0 & $\begin{array}{c}108.8 / 76.7 \\
2.3 / 2.4^{\text {a) }}\end{array}$ & $\begin{array}{c}67.0 \\
2.1\end{array}$ & $\begin{array}{c}104.0 / 72.2 \\
2.1 / 2.6\end{array}$ & $\begin{array}{c}65.5 \\
2.0\end{array}$ \\
\hline 3 & $\begin{array}{c}91.5^{*} / 63.5^{* *} \\
3.2 / 2.1\end{array}$ & $\begin{array}{c}60.7^{* *} \\
1.8\end{array}$ & $\begin{array}{c}89.8^{*} / 62.1^{* *} \\
3.7 / 2.6\end{array}$ & $\begin{array}{c}62.0 \\
2.2\end{array}$ \\
\hline 6 & $\begin{array}{c}95.3^{*} / 61.0^{* *} \\
2.6 / 2.6\end{array}$ & $\begin{array}{c}75.7^{*} \\
2.6\end{array}$ & $\begin{array}{c}95.8^{* *} / 56.5^{* * *} \\
2.1 / 2.5\end{array}$ & $\begin{array}{c}77.3^{* *} \\
2.5\end{array}$ \\
\hline 10 & $\begin{array}{c}99.8^{*} / 65.7^{*} \\
2.4 / 2.6\end{array}$ & $\begin{array}{c}75.0^{*} \\
2.9\end{array}$ & $\begin{array}{c}97.6^{*} / 65.3^{*} \\
2.8 / 2.0\end{array}$ & $\begin{array}{c}68.7 \\
2.5\end{array}$ \\
\hline 24 & $\begin{array}{c}107.7 / 72.3 \\
3.1 / 2.1\end{array}$ & $\begin{array}{c}69.3 \\
3.1\end{array}$ & $\begin{array}{c}99.2^{* *} / 66.8 \\
2.4 / 2.7\end{array}$ & $\begin{array}{c}70.3^{\circ} \\
2.4\end{array}$ \\
\hline 48 & $\begin{array}{c}104.8 / 68.7 \\
3.2 / 2.7\end{array}$ & $\begin{array}{c}76.8^{* *} \\
3.4\end{array}$ & $\begin{array}{c}106.5 / 69.3 \\
2.6 / 2.7\end{array}$ & $\begin{array}{c}74.7^{\circ} \\
3.1\end{array}$ \\
\hline
\end{tabular}


highly significant. These results raise the question whether blockade of converting enzyme activity is complete in the face of increased angiotensin I levels.

Relationship between plasma angiotensin II, aldosterone and converting enzyme activity

Figure $4 \mathrm{a}$ illustrates the relationship that exists between the measured plasma angiotensin II levels and

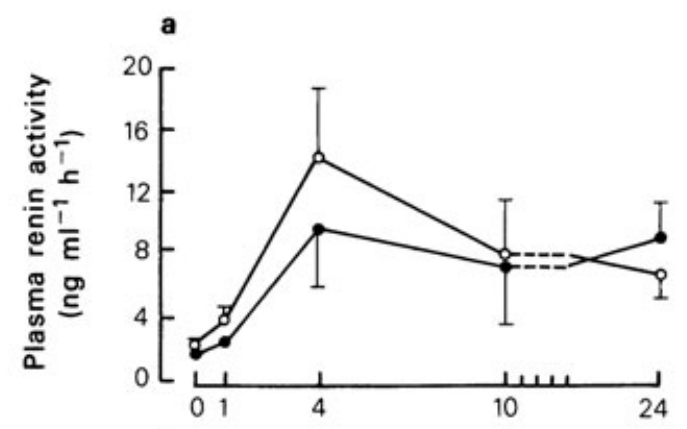

b
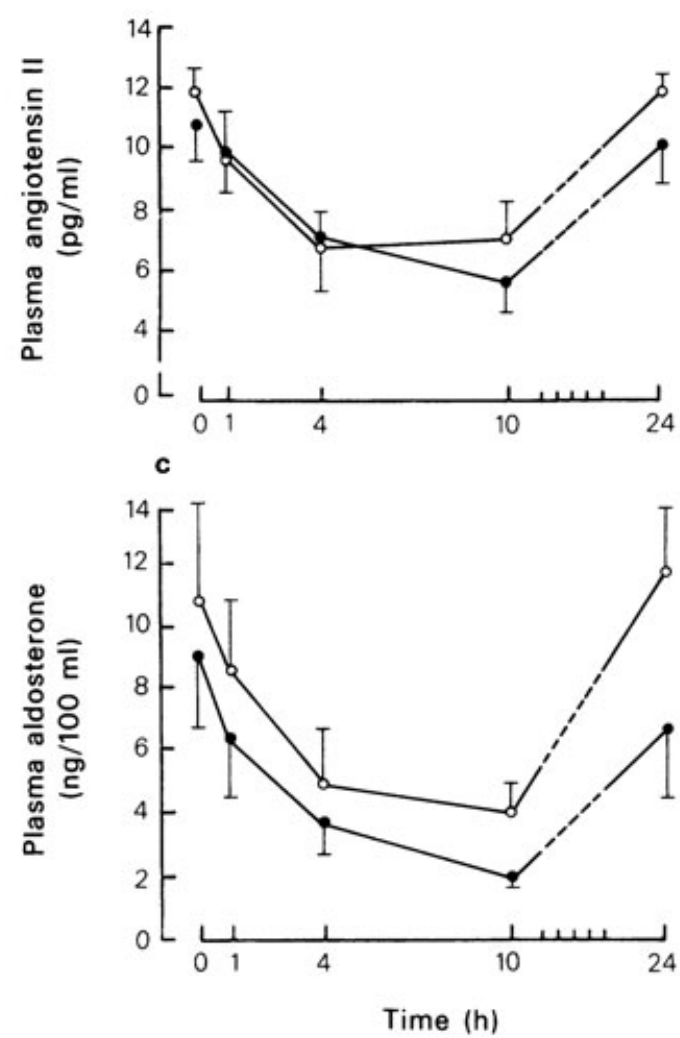

Figure 2 Time course of plasma renin activity (a), plasma angiotensin II (b) and plasma aldosterone (c) following oral administration of $10 \mathrm{mg} \mathrm{MK} 421$ (O) or its lysine analogue (LA, • ) (mean \pm s.e.mean, $n=6)$. plasma converting enzyme activity. It appears that plasma converting enzyme activity has to be reduced well below 20 or even $10 \mathrm{nmol} \mathrm{ml}^{-1} \mathrm{~min}^{-1}$ in order to significantly reduce plasma angiotensin II. In Figure $4 \mathrm{~b}$, a similar relationship is shown between plasma aldosterone and plasma converting enzyme activity. Again, a considerable reduction in plasma converting enzyme activity is necessary to significantly reduce plasma aldosterone. Not surprisingly, in the light of these combined findings, Figure $4 \mathrm{c}$ shows that there exists a positive correlation between plasma aldosterone and plasma angiotensin II levels during plasma converting enzyme blockade such that when plasma angiotensin II is reduced plasma aldosterone also decreases.

\section{Electrolyte excretion}

During the 4 day observation period, urinary potassium excretion expressed as potassium/creatinine ratio did not change as a result of the administration of either MK 421 or the lysine analogue (Figure 5a). In contrast, on the day of administration of either one of the inhibitors (day 1) urinary sodium/creatinine ratio (Figure $5 \mathrm{~b}$ ) increased significantly from $10.6 \pm$ $1.5(\mathrm{MK} 421)$ and $10.0 \pm 1.5(\mathrm{LA})$ to $16.2 \pm 1.9$ and $17.3 \pm 2.8$ respectively $(\mathrm{P}<0.05)$. That the increased sodium excretion following drug administration was indeed related to the decrease in aldosterone is suggested by Figure $5 \mathrm{c}$. It describes a close inverse correlation between the logarithm of plasma aldosterone and the hourly urinary sodium excretion during the $10 \mathrm{~h}$ following drug administration such that when plasma aldosterone levels were low sodium excretion increased $(P<0.001)$.

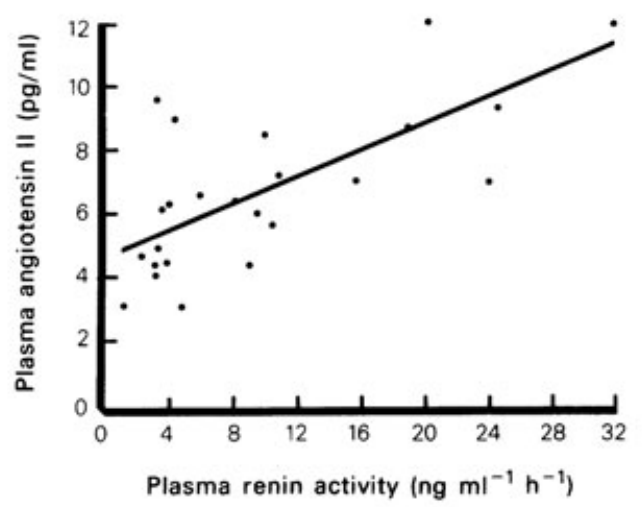

Mk 421

LA

Figure 3 Correlation between plasma angiotensin II and plasma renin activity during peak converting enzyme blockade, i.e. 4 and $10 \mathrm{~h}$ following oral administration of $10 \mathrm{mg}$ MK 421 or its lysine analogue (LA). $(\mathrm{y}=0.21 \mathrm{x}+4.64, n=24, r=0.71, P<0.001)$. 


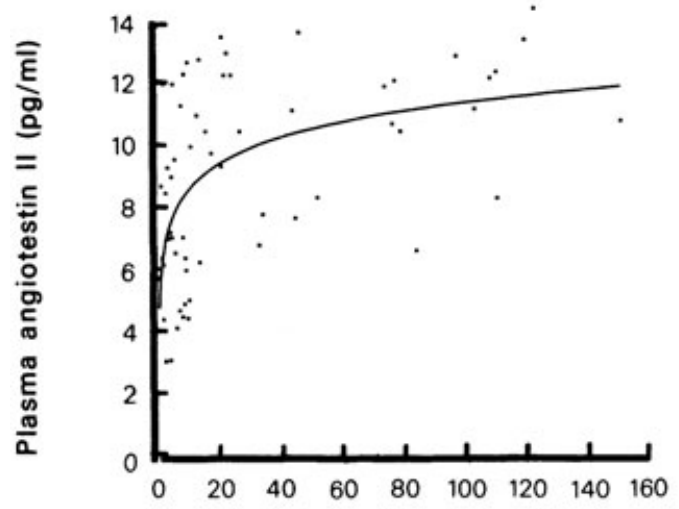

Plasma converting enzyme activity (nmol $\mathrm{ml}^{-1} \mathrm{~min}^{-1}$ )

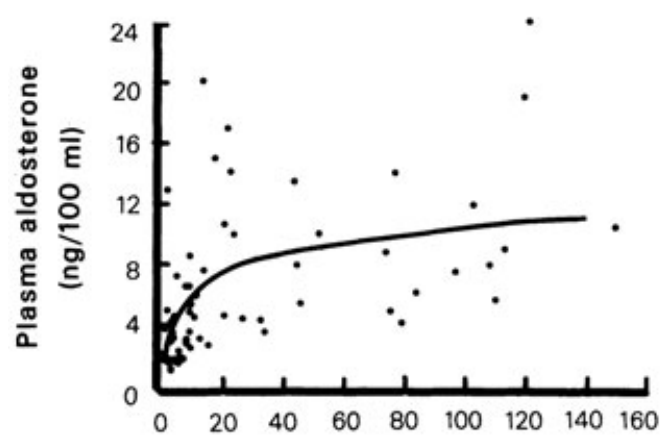

Plasma converting enzyme activity (nmol $\mathrm{ml}^{-1} \mathrm{~min}^{-1}$ )

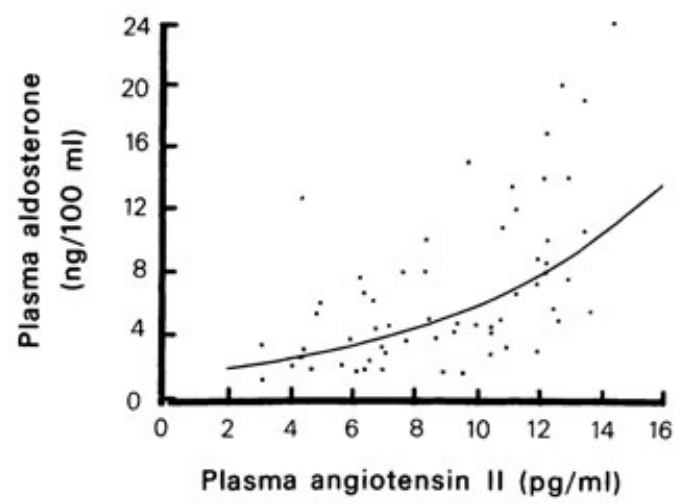

Figure 4 Correlations between plasma angiotensin II (a, $\mathrm{y}=1.27 \ln \mathrm{x}+5.64, n=60, r=0.54, P<0.001)$, plasma aldosterone (b, $y=1.95 \ln x+1.53, n=60, r=$ $0.52, P<0.001)$ and plasma converting enzyme activity following oral administration of $10 \mathrm{mg}$ MK 421 or its lysine analogue (LA). (c) illustrates the relationship between plasma angiotensin II and plasma aldosterone during the same time $\left(y=1.49 e^{0.14 x}, n=60, r=0.60\right.$, $P<0.001$ ).
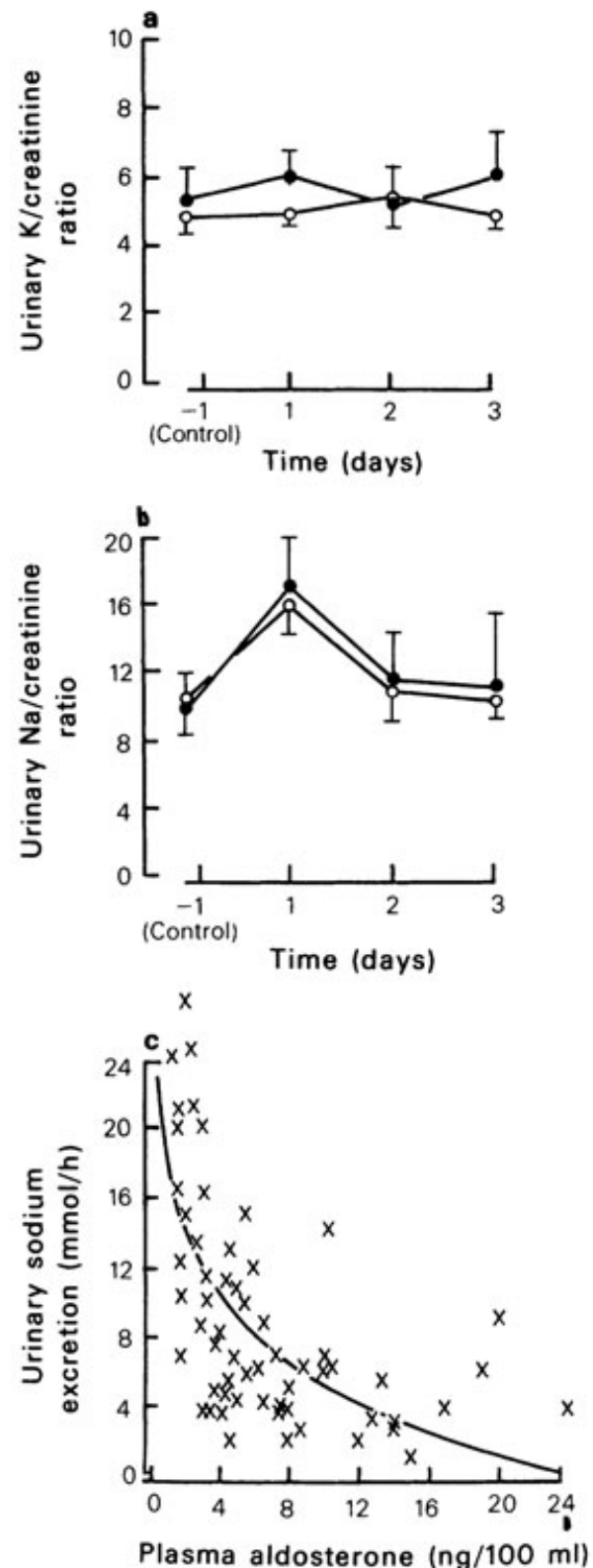

Figure 5 (a) Urinary potassium excretion (mean \pm s.e. mean, $n=12$ ) expressed as urinary potassium/ creatinine ratio on the day prior (day -1) and the 3 days following $(1,2,3)$ oral administration of $10 \mathrm{mg}$ MK 421 (O) or its lysine analogue (LA, ).

(b) Urinary sodium excretion exhibited in identical fashion.

(c) Relationship between the urinary sodium excretion rate preceding each plasma aldosterone determination and the corresponding plasma aldosterone level following oral administration of $10 \mathrm{mg}$ MK $\mathbf{4 2 1}$ or its lysine analogue (LA) $(y=18.88-5.83 \ln x, n=60, r=$ $0.66, P<0.001)$. 


\section{Discussion}

MK421 and its lysine analogue are two new potent orally active inhibitors of converting enzyme. Their recent development is of great practical interest since they do not contain any mercapto group which at present is thought to be mainly responsible for the side effects observed with captopril, the only orally active inhibitor available so far. As we have shown previously, MK 421 and its lysine analogue markedly blunt the pressor effect of exogenous angiotensin I (Biollaz et al., 1981). The present study quantifying the time course of the changes of the components of the renin angiotensin system confirms the earlier impression that both compounds have a considerably longer duration of action than captopril. Thus. plasma angiotensin II and aldosterone were still markedly reduced $10 \mathrm{~h}$ following administration of the drugs and plasma converting enzyme activity had not returned to baseline levels even $72 \mathrm{~h}$ following administration of either MK 421 or LA. This contrasts clearly with captopril. since already 12 to 14 $\mathrm{h}$ after its oral administration plasma converting enzyme activity returns to baseline levels (Waeber. Brunner. Brunner. Curtet. Turini \& Gavras, 1980).

Since the measurement of plasma angiotensin converting enzyme activity seems to be a useful tool to monitor patient compliance and drug efficacy, it is important to point out the stability of the in vitro complex that presumably is formed between the inhibiting compounds and converting enzyme. Whereas several investigators have reported that during plasma storage captopril dissociates from converting enzyme thus revealing higher levels of converting enzyme activity (Roulston, McGregor \& Bird, 1980), we have not observed this phenomenon with the present two compounds (see Figure 1). This apparent stability of the complex is probably of great importance for the efficacy and the duration of action of these inhibitors.

The present data confirm that plasma converting enzyme activity has to be reduced below at least 20 and probably even $10 \%$ of control in order to induce effective blockade of the renin system. This is in agreement with our earlier observation using the same compounds that a similar decrease in plasma converting enzyme activity was necessary to block the pressor response to exogenous angiotensin I (Biollaz et al., 1981). As already proposed (Waeber et al., 1980) plasma converting enzyme activity closely reflects the global activity of this enzyme which occurs predominantly in the endothetial cells of the pulmonary capillaries ( $\mathrm{Ng} \&$ Vane. 1967). The determination of plasma converting enzyme activity provides thus a unique opportunity to monitor biochemically with a relatively simple assay the specific pharmacological effect of these drugs.

Blood pressure of these normal volunteers de- creased significantly following administration of both converting enzyme inhibitors. For the purpose of the study the subjects were seated for more than $10 \mathrm{~h}$ in a comfortable armchair only getting up once every $2 \mathrm{~h}$ to void and once to eat lunch. Since we never intended to investigate a potential hypotensive effect of the drugs in these subjects we did not include a placebo controlled group. It is therefore not possible to decide whether the blood pressure drop was due to converting enzyme inhibition per se. i.e. reduced angiotensin II levels, or rather just related to the prolonged inactivity of the subjects, or both. Accordingly, the effect of these drugs on the blood pressure of normotensive subjects remains to be investigated further. Nevertheless, in a recent unpublished study using a similar design, prolonged sitting did not reduce blood pressure.

The positive correlation between plasma renin activity and angiotensin II levels observed during peak blockade, i.e. 4 and $10 \mathrm{~h}$ following administration of the converting enzyme inhibitors, needs some comments. At first glance one might interpret these findings as a methodological artefact due to cross reacting of high angiotensin I levels with angiotensin II antibodies used in the angiotensin II radioimmunoassay, as some investigators have observed. However, cross-reactivity of angiotensin I with our angiotensin II antibodies was found to be less than $1 / 1000$. Angiotensin I levels were actually measured in 9 of the 12 studies in which angiotensin II, aldosterone and renin activity were determined. Angiotensin I levels rose from a control of $12.9 \pm 1.1 \mathrm{pg} / \mathrm{ml}$ to 80.4 $\pm 26.6 \mathrm{pg} / \mathrm{ml}$ at 4 and $57.8 \pm 20.0 \mathrm{pg} / \mathrm{ml}$ at $10 \mathrm{~h}$ with the highest level ever measured being at $245 \mathrm{pg} / \mathrm{ml}$. Accordingly, on the average, cross reactivity could only account for less than $0.1 \mathrm{pg} / \mathrm{ml}$ and at most for $0.25 \mathrm{pg} / \mathrm{ml}$. Therefore, the observed correlation does not seem to be due to cross-reactivity and we believe that it rather reflects incompleteness of the blockade such that still small amounts of angiotensin I are converted to angiotensin II. Whether this residual conversion of angiotensin I to angiotensin II is of any physiological and/or clinical significance remains to be established. It may suggest however that higher doses will be needed at least in some patients to effectively treat their hypertension.

Another finding of the study is the increased natriuresis on the day of drug administration. Again one might wonder whether remaining seated for a prolonged period of time could have contributed to this effect. However, the magnitude of the natriuresis is such that it seems unlikely to be related exclusively to the posture of the volunteers. Furthermore, the inverse correlation that was found between hourly urinary sodium excretion and plasma aldosterone levels suggests that the increased natriuresis was indeed related to the decrease in aldosterone levels and thus represents a drug action. The combination of 
increased natriuresis together with blockade of the renin system would seem a desirable feature of a new anti-hypertensive drug, if it can be demonstrated in hypertensive patients. Increased natriuresis usually has not been observed when giving captopril to hypertensive patients (Brunner et al., 1979). However, due to the prolonged duration of action of this new group of inhibitors it is conceivable that their natriuretic potential is greater than that observed with captopril since aldosterone can be reduced continuously.

In conclusion, MK 421 and its lysine analogue induce remarkable inhibition of angiotensin converting

\section{References}

BIOLLAZ, J., BURNIER, M., TURINI, G., BRUNNER, D.B.. PORCHET, M., GOMEZ, H.J., JONES, K.H., FERBER, F., ABRAMS, W.B., GAVRAS. H.\& BRUNNER, H.R. (1981). Three new long-acting converting enzyme inhibitors: relationship between plasma converting enzyme activity and repsonse to angiotensin $I$ in normal volunteers. Clin. Pharmac. Ther., (in press).

BRITISH MEDICAL JOURNAL (1980). Editorial. Inhibitors of angiotensin I converting enzyme for treating hypertension. Br. med. J., 281, 630-631.

BRUNNER, H.R., GAVRAS, H., WAEBER, B., KERSHAW, G.R., TURINI, G.A., VUKOVICH, R.A., McKINSTRY, D.N. \& GAVRAS, I. (1979). Oral angiotensin-converting enzyme inhibitor in long-term treatment of hypertensive patients. Ann. int. Med., 90, 19-23.

CASE, D.B., ATLAS, S.A., LARAGH, J.H., SEALEY, J.E. SULLIVAN, P.A. \& McKINSTRY, D.N. (1978). Clinical experience with blockade of the renin-angiotensinaldosterone system by an oral converting-enzyme inhibitor (SQ 14,225, captopril) in hypertensive patients. Progr. Cardiovasc. Dis., 21, 195-206.

DAVIS, R., RIBNER, H.S., KEUNG, E., SONNENBLICK, E. H. \& LEJEMTEL, T.H. (1979). Treatment of chronic congestive heart failure with captopril, an oral inhibitor of angiotensive-converting enzyme. New Engl. J. Med., 301, 117-121.

DÜSTERDIECK, G. \& McELVEE, G. (1971). Estimation of angiotensen II concentration in human plasma by radioimmunoassay. Some applications to physiological and clinical states. Eur. J. clin. Invest., 2, 32-38. enzyme in healthy subjects. This effect. is highly reproducible and of long duration. The complex formed between the inhibitors and plasma converting enzyme seems very stable. Both compounds induce significant natriuresis. In addition, the absence of a mercapto group in these drugs makes it attractive to speculate that side effects similar to those observed with captopril may occur less frequently.

Reprint requests should be addressed to Dr D.B. Brunner. Department of Medicine, CHUV, 1011 Lausanne. Switzerland.

FERGUSON, R.K., TURINI, G.A., BRUNNER, H.R. GAVRAS, H. \& McKINSTRY, D.N. (1977). A specific orally active inhibitor of angiotensin-converting enzyme in man. Lancet, i, 775-778.

GAVRAS, H., BRUNNER, H.R., TURINI, G.A., KERSHAW, G.R., TIFFT, C.P., CUTTELOD, S., GAVRAS, I. VUKOVICH, R.A. \& McKINSTRY, D.N. (1978). Antihypertensive effect of the oral angiotensin converting-enzyme inhibitor SQ 14,225 in man. New Engl. J. Med., 298, 991-995.

NG, K.K.F. \& VANE, J.R. (1967). Conversion of angiotensen I to angiotensin II. Nature, 216, 762-766.

ROULSTON, J.E., McGREGOR, G.A. \& BIRD, R. (1980). The measurement of angiotensin-converting enzyme in subjects receiving captopril. New Engl. J. Med., 303, 397.

TURINI, G.A., BRUNNER, H.R., GRIBIC, M., WAEBER, B. \& GAVRAS, H. (1979). Improvement of chronic congestive heart-failure by oral captopril. Lancet, i, 1213-1215.

WAEBER, B., BRUNNER, H.R., BRUNNER, D.B., CURTET, A.L., TURINI, G.A. \& GAVRAS, H. (1980). Discrepancy between antihypertensive effect and angiotensin converting enzyme inhibition by captopril. Hypertension, 2 , 236-242.

WAITE, M.A. (1973). Measurement of concentrations of angiotensin I in human blood by radioimmunoassay. Clin. Sci., 45, 51-64.

(Received December 9, 1980) 